\title{
Alcohol enhances efficiency of performance in a repetitive alternation task
}

\author{
LOWELL T. CROW \\ Western Washington University, Bellingham, Washington
}

\begin{abstract}
Rats were trained in a two-bar alternation task for water reward. A right barpress (RB) was required within a time window of 2-3 sec after a left barpress (LB) for reinforcement. Measures of total responses, proportion of RBs to total responses, total number of reinforcements, proportion of reinforcements to total responses, uncertainty of LB-RB response sequences, and LB-RB latency were taken after control (saline) and ethyl alcohol $(0.65-0.75 \mathrm{~g} / \mathrm{kg})$ ip injections. Alcohol produced a disproportionate decrease in RBs, an increase in number of reinforcements per response, and a decrease in the uncertainty of LB-RB sequences. The results are discussed in terms of the behavioral-variability hypothesis of alcohol effects.
\end{abstract}

The depressive effects of alcohol upon behavior are well documented, but for some tasks, low levels of alcohol intoxication may alter behavior so as to stimulate certain aspects of performance. With an assumption that the behavioral effects of alcohol may be subsumed under the concept of behavioral variability (Crow, 1985; Devenport \& Merriman, 1983), a task was chosen for which increased stereotypy of responding would result in improved performance, and doses of alcohol were selected in an attempt to maximize behavioral stereotypy while minimizing response suppression for this task.

\section{METHOD}

\section{Subjects}

Twelve male albino rats from Tyler Laboratories, Bellevue, Washing-

Address correspondence to L. T. Crow, Department of Psychology, Western Washington University, Bellingham, WA 98225. ton, were used. They were approximately 90 days of age at the start of training.

\section{Apparatus}

A Grason-Stadler two-bar operant chamber, modified for water delivery, was used in conjunction with an Atari $800 \mathrm{XL}$ PC.

\begin{abstract}
Alcohol
A $10 \%$ aqueous solution (W/V) of $95 \%$ ethanol was injected ip $10 \mathrm{~min}$ prior to test in an amount of either 0.65 or $0.75 \mathrm{~g} / \mathrm{kg}$. Control injections consisted of isotonic saline.

\section{Procedure}

Over a 90-day period, animals were trained in 10-min daily sessions, each followed by a 30-min period of free access to water. The early training sessions consisted of a left barpress (LB) reinforcement; later training of a right barpress $(\mathrm{RB})$ reinforcement, then of reinforcement of either barpress, followed by LB-RB sequence reinforcement, and finally, of reinforcement of LB-RB sequences of no less than $2 \mathrm{sec}$ and no more than $3 \mathrm{sec}$.

After responding had stabilized for the time-restricted alternation schedule, injections of saline or alcohol were given using each animal as its own control. All animals received multiple injections, allowing one week between treatments; an alcohol dose was sought above $0.5 \mathrm{~g} / \mathrm{kg}$ for which
\end{abstract}

Table 1

Means (M) and Standard Deviations (SD) of Pretreatment and Control-Alcohol Conditions for the Response Measures

\begin{tabular}{|c|c|c|c|c|c|c|c|}
\hline & \multicolumn{2}{|c|}{$\begin{array}{l}\text { Pretreatment } \\
\quad(\mathrm{N}=12)\end{array}$} & \multicolumn{2}{|c|}{$\begin{array}{l}\text { Control } \\
(\mathrm{N}=8)\end{array}$} & \multicolumn{3}{|c|}{$\begin{array}{l}\text { Alcohol } \\
(\mathrm{N}=8)\end{array}$} \\
\hline & $\mathbf{M}$ & SD & $\mathbf{M}$ & SD & $\mathbf{M}$ & SD & $\mathbf{P}$ \\
\hline $\begin{array}{l}\text { Total } \\
\text { Responses }\end{array}$ & 199.3 & 60.6 & 167.3 & 90.0 & 103.5 & 88.7 & .254 \\
\hline $\begin{array}{l}\text { RB/Total } \\
\text { Responses }\end{array}$ & .71 & .09 & .70 & .084 & .60 & .142 & .020 \\
\hline $\begin{array}{l}\text { Total } \\
\text { Reinforcements }\end{array}$ & 44.6 & 14.7 & 39.0 & 12.9 & 30.89 & 22.1 & .363 \\
\hline $\begin{array}{l}\text { Reinforcements } \\
\text { Total } \\
\text { Responses }\end{array}$ & .230 & .062 & .257 & .091 & .405 & .203 & .004 \\
\hline Uncertainty & .732 & .129 & .791 & .067 & .626 & .264 & .004 \\
\hline $\begin{array}{l}\text { Response } \\
\text { Latency }\end{array}$ & 11.48 & 7.76 & 11.24 & 15.31 & 37.4 & 84.8 & .254 \\
\hline
\end{tabular}


the animals would respond. Four animals did not respond to doses above this level. The maximal dose for 3 of the remaining animals was $0.65 \mathrm{~g} / \mathrm{kg}$, and for the other $5,0.75 \mathrm{~g} / \mathrm{kg}$. Data from animals receiving the latter doses were pooled in the analysis

\section{RESULTS AND DISCUSSION}

Table 1 summarizes the means and standard deviations for each measure of the 8 animals from which all data were collected, as well as for the pretreatment data for all 12 animals. Probabilities are based upon binomial-sign tests. General depressant effects are evident, but cannot explain all the data. In addition, a selective depression of "excessive" responding seems to have occurred. Alcohol resulted in a disproportionate decrease in RBs, which, under the present conditions, produced an increased number of reinforcements per barpress. For rats under alcohol, a greater number of RBs occurred within the reinforcement window than under control conditions, and, consistent with this, the uncertainty of LB-RB sequences (Frick \& Miller, 1951) was reduced by the drug.

The results are in keeping with other findings of ethanolinduced response stereotypy (Crow, McWilliams, \& Ley, 1979; Devenport \& Merriman, 1983) and confirm the prediction that performance on tasks requiring stereotypic timing behaviors may be enhanced by alcohol.

\section{REFERENCES}

Crow, L. T. (1985). More on behavioral variability. Psychological Record, 35, 293-300.

Crow, L. T., McWilliams, L. S., \& Ley, M. F. (1979). Relative stereotypy of water-ingestive behavior induced by chronic alcohol injections in the rat. Bulletin of the Psychonomic Society, 14, 278-280.

Devenport, L. D., \& Merriman, V. J. (1983 ). Ethanol and behavioral variability in the radial-arm maze. Psychopharmacology, 47, 157-164.

FrICK, F. C., \& MiLler, G. A. (1951). A statistical description of operant conditioning. American Journal of Psychology, 64, 20-36. 